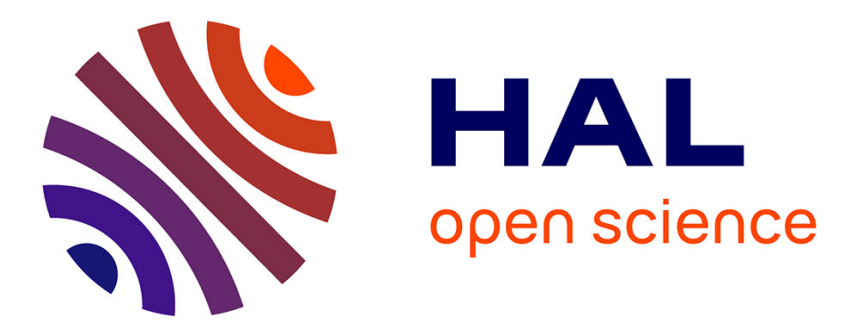

\title{
Antibiotic Resistant Bacteria As Bio-Indicator Of Polluted Effluent In The Green Turtles, In Oman
}

Saif N. Al-Bahry, Ibrahim Y. Mahmoud, Maheera Al-Zadjali, Abdulkader Elshafie, Asila Al-Harthy, Wafaa Al-Alawi

\section{- To cite this version:}

Saif N. Al-Bahry, Ibrahim Y. Mahmoud, Maheera Al-Zadjali, Abdulkader Elshafie, Asila Al-Harthy, et al.. Antibiotic Resistant Bacteria As Bio-Indicator Of Polluted Effluent In The Green Turtles, In Oman. Marine Environmental Research, 2011, 71 (2), pp.139. 10.1016/j.marenvres.2010.12.005 . hal-00664003

\section{HAL Id: hal-00664003 https://hal.science/hal-00664003}

Submitted on 28 Jan 2012

HAL is a multi-disciplinary open access archive for the deposit and dissemination of scientific research documents, whether they are published or not. The documents may come from teaching and research institutions in France or abroad, or from public or private research centers.
L'archive ouverte pluridisciplinaire HAL, est destinée au dépôt et à la diffusion de documents scientifiques de niveau recherche, publiés ou non, émanant des établissements d'enseignement et de recherche français ou étrangers, des laboratoires publics ou privés. 


\section{Accepted Manuscript}

Title: Antibiotic Resistant Bacteria As Bio-Indicator Of Polluted Effluent In The Green Turtles, Chelonia Mydas In Oman

Authors: Saif N. Al-Bahry, Ibrahim Y. Mahmoud, Maheera Al-Zadjali, Abdulkader Elshafie, Asila Al-Harthy, Wafaa Al-Alawi

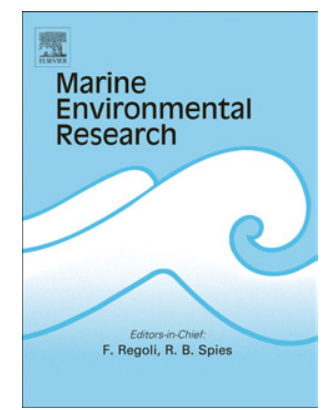

PII: S0141-1136(10)00193-5

DOI: 10.1016/j.marenvres.2010.12.005

Reference: MERE 3493

To appear in: Marine Environmental Research

Received Date: 1 May 2009

Revised Date: 17 December 2010

Accepted Date: 20 December 2010

Please cite this article as: Al-Bahry, S.N., Mahmoud, I.Y., Al-Zadjali, M., Elshafie, A., Al-Harthy, A., Al-Alawi, W. Antibiotic Resistant Bacteria As Bio-Indicator Of Polluted Effluent In The Green Turtles, Chelonia Mydas In Oman, Marine Environmental Research (2010), doi: 10.1016/ j.marenvres.2010.12.005

This is a PDF file of an unedited manuscript that has been accepted for publication. As a service to our customers we are providing this early version of the manuscript. The manuscript will undergo copyediting, typesetting, and review of the resulting proof before it is published in its final form. Please note that during the production process errors may be discovered which could affect the content, and all legal disclaimers that apply to the journal pertain. 


\section{ANTIBIOTIC RESISTANT BACTERIA AS BIO-INDICATOR OF POLLUTED EFFLUENT IN THE GREEN TURTLES, Chelonia mydas IN OMAN}

Saif N. Al-Bahry ${ }^{1}$, Ibrahim Y. Mahmoud ${ }^{1}$, Maheera Al-Zadjali ${ }^{1}$, Abdulkader Elshafie ${ }^{1}$, Asila Al-Harthy ${ }^{1}$, and Wafaa Al-Alawi.

${ }^{1}$ Department of Biology, College of Science, Sultan Qaboos University, P.O.Box 36, P.C. 123, Al-Khodh, Oman.

Author for correspondence:

Saif Al-Bahry

Tel: (968) 24141449

Fax: (968) 24141437

E-mail: snbahry@squ.edu.om 


\begin{abstract}
Antibiotic resistant bacteria were studied as bio-indicators of marine polluted effluents during egg-laying in green turtles. A non-invasive procedure for sampling oviductal fluid was used to test for exposure of turtles to pollution in Ras Al-Hadd, Oman, which is one of the most important nesting beaches in the world. Each sample was obtained by inserting a $15 \mathrm{~cm}$ sterile swab gently into the cloacal vent as the sphincter muscle is relaxed and the cloacal lining is unfolded to the outside. Forty turtles were sampled. A hundred and thirty-two species of bacteria from 7 genera were isolated. The dominant isolate was Citrobacter. Among the isolates $60.6 \%$ were multiple resistant to 15 tested antibiotics. The dominant resistance to antibiotics was ampicillin followed by streptomycine and sulphamethoxazole. Sampling oviductal fluid for resistant bacteria to antibiotics is valuable way to assess exposure to polluted effluents during feeding and migratory in turtles. Polluted effluents using bacteria as bio-indicator may influence reproductive potential in this endangered species.
\end{abstract}

KEY WORDS: Bacteria, Antibiotics, Bio-indicator, Oviductal fluid, Pollution, Green turtles. 


\section{INTRODUCTON}

Evidence of increasing resistance to antibiotics in bacteria suggests that anti-microbial drugs play a major role in the emergence of multiple resistant bacteria (Refsdal, 2000). Berger-Bächi, (2002) reported that in the last few decades there was an increase in number and severity of infections arising from such bacteria. These pathogens have a tendency to accumulate multiple resistance factors under antibiotic selection Antibiotics enter the environment via different pathways. Resistant bacteria may have been selected during the process of sewage treatment and, subsequently, may reach the aquatic environment via contaminated effluents (Kümmerer, 2001; Hühnerfuss, 2003).

The rapid development of resistance is due to mutational events and/or gene transfer and acquisition of resistant determinants, allowing strains to survive antibiotic treatment (Berger-Bächi, 2002; Alonso, et al., 2001). The development of antibiotics, from the sulphonamides used in the past to the powerful broad spectrum antibiotics of today, has led to a fundamental disturbance of microbial ecology (Spratt, 2004). The use of antibiotics directly selects resistant variants to different antibiotics or disinfectants (Jeljaszewicz et al., 2000).

Antibiotic resistant bacteria have been reported in wild birds and mammals, even from remote regions such as the Amazon River Basin (Kempski et al., 2005). Antibiotic resistant bacteria were also isolated from juvenile loggerhead sea turtles (Caretta caretta) in Cour Sound, North Carolina, USA (Harms et al., 2006). Antibiotic resistant bacteria have also been found in the egg shells and egg contents of the green turtle, Chelonia mydas (Al-Bahry et al., 2009a). The source of bacterial contamination to the eggs was 
unknown. In the present investigation we analyzed the oviductal fluid during the egglaying process in order to find the source of contamination that we previously reported. In this investigation a simpler non-invasive sample method was designed specifically to collect oviductal fluid in the egg-laying green turtles and to isolate bacterial flora and resistant bacteria to antibiotics.

Resistant bacteria were used as bio-indicator for the presence of the contaminated effluents in the marine turtles (Al-Bahry et al., 2009a, Al-Bahry et al., 2009b, Foti et al., 2009 and Foti et al., 2008). This data will be valuable in the overall assessment of pollution of feeding habitats, as well as the migratory routes of the green turtles.

\section{MATERIALS AND METHODS}

\section{Study area.}

Ras Al-Hadd Reserve is located on the Gulf of Oman and the Arabian Sea between $22^{\circ}$ $32^{\prime} \mathrm{N}$ and $59^{\circ} 45^{\prime} \mathrm{E}$ and $22^{\circ} 14^{\prime} \mathrm{N}$ and $59^{\circ} 48^{\prime} \mathrm{E}$. The northern $4 \mathrm{~km}$ of the Reserve are located on the Gulf of Oman, while the rest of the Reserve is located on the Arabian Sea. The coastline is mostly sheltered by rocky hills. High-energy waves build a curb of sand that can rise $2 \mathrm{~m}$ high. Approximately 20 beaches with different lengths ( $50 \mathrm{~m}$ to $5.3 \mathrm{Km})$ make up the Reserve. Most of these sheltered beaches are considered ideal nesting grounds for the green turtles.

\section{Brief description of the reproductive tract in turtles:}

The oviduct (the reproductive tract) is divided into four regions: infundibulum, uterine, uterus and vagina (Alkindi et al., 2006). The vagina is directly connected to the cloaca (Fig 2b). The gastrointestinal tract and ureters make a connection to the cloaca by the sphincter vent (Fig 2a and 2b). During the egg-laying process the turtle periodically 
secretes clear fluid over its eggs which are synthesized by special glands of the uterus, vagina and cloaca. In this paper the term oviductal fluid is used to describe this secretion.

\section{Sample collection:}

Oviductal fluid samples were collected by inserting a $15 \mathrm{~cm}$ long sterile swab gently. The swab was easily inserted into the cloacal vent due to the general relaxation of the sphincter muscle as well as the unfolding of the smooth lining of the cloaca and the moist condition of the lumina (Fig 1a and 1b). During the course of oviposition, the turtle discharges oviductal fluid over the eggs which keeps them moist, as the cloacal sphincter is projected into the neck of the nesting chamber without touching the rim of the nest. This method has not been used by other investigators in the egg-laying turtles. This method was specifically designed to collect bacteria during the egg-laying process. Thus, the swabbing technique was necessary in this study.

A total of forty turtles were examined. The samples from each turtle were collected after the turtle had discharged oviductal fluid over the eggs at least three times during the course of oviposition, which ensured that most residual bacterial flora in the cloaca had been flushed away. During the oviposition the cloaca was projected into the opening of the nesting chamber. The unfolded smooth cloacal lining was not contaminated with sand at anytime and we did not observe any sand grains on the swabs (Fig 1a and 1b). The cloacal vent folds in after egg-laying is completed.

\section{Isolation of bacteria:}

Four swabs were taken from each turtle, three being used to inoculate the following selective media; selenite-F, alkaline peptone and lactose broth-containing Durham tubes. 
The other swab was directly streaked on nutrient agar. All media used in this study were obtained from Oxoid, UK.

The contents were then incubated in a portable incubator at $37^{\circ} \mathrm{C}$ for $24-48$ hours. After inoculation, the tubes were streaked on the corresponding differential, selective media; Salmonella-Shigella (SS), thiosulfate-citrate-bille-sucrose (TCBS), and eosie-methyleneblue (EMB) agars respectively. The plates were also incubated at $37^{\circ} \mathrm{C}$ for $24-48$ hours. Swabs were also taken from cloacal lumen of five nesting turtles after these turtles finished laying and burying their eggs and began their movement toward the sea. During this time the smooth cloacal lining had returned to its normal inside and folded position (Fig $2 \mathrm{a}$ and $2 \mathrm{~b}$ ). The turtle was then turned on its back, the cloacal vent was cleaned of sand, disinfected and a swab inserted into the cloaca (Fig 1c). However, there was difficulty in inserting the swab beyond $2-3 \mathrm{~cm}$ as the cloaca was withdrawn toward the inside and there was a general constriction in both the cloacal sphincter and the cloacal chamber. Even though the area around the sphincter was aseptically cleaned before insertion of the swab, there were still grains of sand on the swab when retracted from the cloaca. Therefore, this procedure was not used in this study and the data collected was used only for comparison with the data from the present swabbing procedure.

\section{Sand samples:}

Five sand samples near the turtle nests were collected aseptically and were then streaked on nutrient agar plates. The data were used for comparison with the results of egg-laying and the post egg-laying turtles.

\section{Direct Oviductal Fluid Collection}


Oviductal fluid was collected in $15-\mathrm{ml}$ sterile test tubes as the turtle periodically discharged the oviductal fluid. The test tubes were then placed in an ice box and transported to the lab for microbiological analysis. A total of five turtles were sampled.

\section{Identification of the isolates:}

Characteristic colonies were selected and the isolates were identified biochemically by the standard Analytical Profile Index (API) system (New York). The API 20E system was used for identifying Enterobacteriaceae and the fermentative bacteria, while the API 20NE system was used for the identification of Vibrio and Aeromonas and other nonfermentative bacteria. Colonies from nutrient agar plates of the suspected Gram positive bacteria were identified by their cellular morphology using Gram and spore staining techniques.

\section{Antibiotic susceptibility test:}

One hundred and thirty-two bacterial isolates were tested for their susceptibility to antibiotics, using the disk diffusion method (Bauer et al. 1966) and according to the guidelines of the National Committee for Clinical Laboratory Standards (NCCLS). The cultures were incubated for $18-24$ hours at $37^{\circ} \mathrm{C}$ and the inhibition zones were measured.

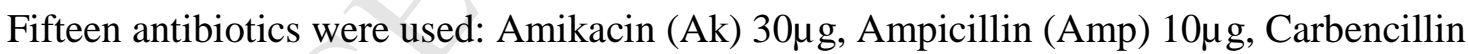

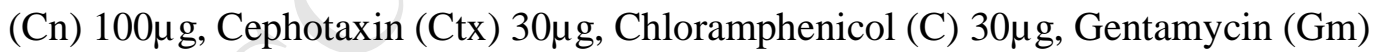

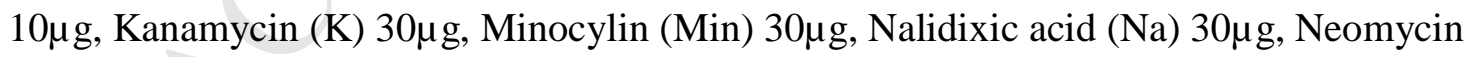

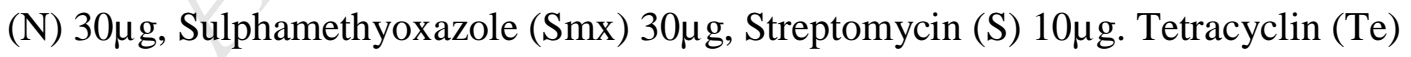
30 $\mu$ g, Tobramycin (Tob) $10 \mu \mathrm{g}$, and Trimethoprim (Tmp) $5 \mu \mathrm{g}$. Inhibition zone diameters were measured after 24 hours of incubation at $37^{\circ} \mathrm{C}$. An Escherichia coli strain (ATCC 
25922) and Pseudomonas aeruginosa strain (ATCC 27853) were used as controls for the disk diffusion assay.

\section{RESULTS}

A total of 132 species of bacteria from 7 genera were isolated from the swabs of the oviductal fluid collected from 40 turtles during the egg-laying process. All the samples contained bacteria. The percentage frequencies of the isolates in the swabs were as follows: Citrobacter spp. (51.4\%), Pasteurella spp. (16.3\%), Pseudomonas spp. (11.6\%), Salmonella spp. (11.6\%), Proteus spp. (4.7\%), Aeromonas spp. (2.1\%), and Shigella spp. (2.3\%). Citrobacter spp dominated the other isolates (Fig 3).

The frequency percentage of bacteria in the turtles isolated from the cloacal vent of the post egg-laying turtles were Bacillus spp (72.1\%), Micrococcus spp. (9.6\%),

Staphylococcus spp (8.9\%), Pseudomonas spp (5.1\%) and Citrobacter spp. (4.3\%). The swabs were contaminated with grains of sand. The sand isolates were Bacillus spp (82.1\%), Micrococuus spp (7.6\%) Staphylococcus spp (6.7\%) and Pseudomonas spp $(3.6 \%)$

Bacterial flora from the oviductal fluid, collected directly in the discharge from the cloacal vent of the nesting turtles, was similar to the bacteria isolated from the swab samples. These isolates were: Citrobacter spp. (47.5\%), Pasteurella spp. (16.7\%), Pseudomonas spp. (14.8\%), Salmonella spp. (14.5\%), Proteus spp. (5.3\%), Aeromonas spp. (1.2\%). Direct fluid collection was not used because of the unpredictable timing of the oviductal fluid discharge and the chance of possible external contamination. Escherichia coli were not present in either the swab samples or the oviductal fluids. 
The isolates from the oviductal fluids were tested against fifteen antibiotics. All the isolates that were resistant to more than one antibiotic were considered to be multiple resistant bacteria. It was shown that $60.6 \%$ of these isolates were resistant to the tested antibiotics. The percentages/ratio of the multiple resistant isolates to the number of antibiotics were as follows: (11\%:1), (16.7\%:2), (38.9\%:3), (13.9\%:4), (5.6\%:9), (5.6\%:10), and (5.6\%:11), and (2.8\%:12) antibiotics (Fig. 4). Among the isolates, the highest resistance to antibiotics was Pseudomonas aeruginosa, which showed resistance to twelve antibiotics.

The majority of the isolates were resistant to ampicillin, streptomycin, and sulphamethoxazole (Fig. 5).

\section{DISCUSSION}

In this study, a swabbing technique was used for isolation of bacteria from the oviductal fluid during the egg-laying process. This procedure allows the examiner to insert a swab that reaches the vaginal lumen easily from where the fluid is secreted. The relaxation response observed during oviposition while the turtle was laying its eggs made it easier to insert the swab into the reproductive tract. This method is gentle and does not disturb the turtles during egg-laying and ensures that the samples are directly collected from the oviductal lumen with minimal contamination. The unfolding of the smooth cloacal lining occurred throughout the period of oviposition in all of the 40 turtles we observed. In the post egg-laying turtle the swab did not go beyond 2-3 cm. During this time, the oviductal fluid was not secreted and the swabbing was limited to the cloaca.

In this study, the oviductal fluid in the egg-laying turtles was heavily contaminated with bacterial flora. A total of 132 species from 7 genera were present. Over half of the 
isolates were Citrobacter spp. Moreover, isolates from the discharged oviductal fluid samples collected directly from the cloacal vent during oviposition were similar to that of the swabbing procedure. However, because of the unpredictability of the timing of oviductal fluid discharge, we did not rely on this procedure.

Isolates from the turtles that had already laid and buried their eggs were entirely different from the egg-laying turtles with exception of Citrobacter and Pseudomonas which were significantly lower than in egg-laying turtles. The dominant isolates in the post egglaying turtles were Bacillus spp.

Surprisingly, the isolates taken from the sand near the nest showed a remarkable similarity to the isolates from turtles that had already buried their eggs, with Bacillus spp being the dominant. In both post egg-laying turtles and sand samples, there were close percentages for Micrococcus, Staphylococcus, and Pseudomonas spp.

Based on the present findings, it appears that the most likely source of contamination in the post egg-laying turtles was from the sand as the turtle was crawling or resting on the sand in a cyclical pattern while burying the eggs (Alkindi et al., 2006). The swabs were heavily contaminated with grains of sand, even though the plastron around the cloacal vent was disinfected and cleaned of sand prior to swabbing. Apparently, the grains of sand can find entry through the cloacal vent during the egg burying process. In addition, forcing the swab through the cloacal vent was difficult and harmful to the post egg-lying turtles due to the general constriction of the cloacal vent and the cloacal wall.

The present results indicate that swabbing after egg-laying does not represent the actual endogenous bacterial flora in the oviductal fluid, since the swab was restricted to only 2-3 $\mathrm{cm}$ beyond the cloacal vent. Moreover, vaginal glands which secrete oviductal fluid are 
located in the vaginal lumen (Alkindi at al., 2003) and secrete fluid only when the turtle lays eggs. Furthermore, the fluid which was collected directly from the vent while the turtle was discharging had similar results of bacterial flora to that of the swabbing technique during egg-laying. The close similarities between bacterial flora from the swabbing technique and the direct fluid collection is a clear indication that the isolates came from the same origin.

After ovulation, the eggs remain in the uterus for about two weeks for the shelling process which involves the formation of eggshell and eggshell membrane. Histological examination has revealed that there are secretory glands throughout the reproductive tract, secreting fluid during the process of eggshell formation and oviposition (Alkindi et al., 2006). During this time the eggs have enough time to be exposed to the contaminated oviductal fluid (Al-Bahry, 2009a).

In the green turtle, the eggs were collected directly from the cloacal vent while the turtles were burying eggs. Examination of freshly laid eggs revealed that the bacterial flora can penetrate all egg components, including eggshell, eggshell membrane, albumen and yolk (Al-Bahry 2009a).

Recent investigators have shown that ovaries and oviducts in chickens may be infected with microbes, which can be deposited inside the eggs before they are laid (Wang and Slavik, 1998; Berrang et al., 1999). This is known as vertical transmission. Also, the eggs can become horizontally contaminated with microbes if they are mixed with contaminated fecal material or other sources in the environment (Catalano and Knabel, 1994). 
In this study, no Escherichia coli were found either in the oviductal fluid samples during the egg laying period. This may suggest that during the swabbing procedure the samples were not contaminated by fecal materials. However, we do not rule out the possibilities of fecal contamination when the fluid passes through the cloacal chamber. Other investigators have isolated fecal coliforms in non-egg laying turtles (Foti et al. 2009 Harms et al., 2006, and Santoro et al., 2006).

In this study we used antibiotic resistant bacteria as bio-indicators of polluted effluents contaminating marine habitats and migratory routes. More than $60 \%$ of the isolates were resistant to antibiotics. The antibiotic resistant bacteria in marine turtles were used as bioindicators of marine pollution by contaminated effluents (Al-Bahry et al., 2009a; and Foti et al 2009). We hope that this non-invasive swabbing method will complement the previous method in assessing the degree of pollution in feeding and migratory habitats of marine turtles.

In this study, high levels of multi-drug resistance for Pseudomonas aeruginosa were found, and that resistance to ampicillin was the highest among the tested isolates. Preliminary study by Harms et al., (2006) reported high levels of multi-drug resistance among Pseudomonas aeruginosa isolates in the juvenile loggerhead sea turtles, (Caretta caretta) and resistance to penicillin and cephotaxin was almost $100 \%$.

The development of multiple resistance to antibiotics is believed to be a result of widespread release of disinfectants and pharmaceutical products related to agriculture, human and veterinary practices (Guardabassi et al., 1998; Kempski et al., 2005, Kümmerer, 2009a, Kümmerer, 2009b). The extensive use of antibiotics in both human and veterinarian medicine, together with agricultural runoff and coastal development, 
results in an increase in antibiotic resistant bacteria. Thus, marine animals are exposed to antibiotic residues and to multiple antibiotic resistant bacteria (Al-Bahry et al., 2009a and b, Foti et al., 2009, Kumerer, 2009a and b; Miranda and Zemelman, 2001, Schmidt et al., 2000). It was also reported that antibiotic resistant bacteria from pelagic fish captured in the Concepcion Bay, Chile revealed a high incidence of resistance found among the isolates (Miranda and Zemelman, 2001). Al-Bahry et al., (2009b) reported that there is strong evidence that infection of fish by antibiotic resistant bacteria is directly related to the treated sewage effluent. Multiple resistant bacteria to antibiotics remain viable in sewage treated effluent even after disinfection and was disseminated in the marine environment (Al-Bahry et al., 2009c).

Hühnerfuss, 2003, reported that the use of pharmaceuticals can find its way into the environment via different pathways. Compounds applied in human medicine and their metabolites are released through urine and feces into sewer systems.

The presence of antibiotic resistant bacteria in marine animals, such as the green turtle, acts as an indicator of pollution in marine habitats. The Ministry of Regional Municipalities, Environment and Water Resources (MRMEWR, 2006), observed that the migration patterns of the green turtles involve a wide geographical region including the Arabian Gulf, Arabian Sea and the northern sector of the Indian Ocean. Thus, the green turtles are exposed to different polluted effluents in their feeding grounds as well as their migratory routes. Thus, it is not practical to survey all the localities along the migratory routes for the presence of pollution. Therefore, monitoring the presence of the antibiotic resistant bacteria is more practical and valuable for detection of the magnitude of pollution along the migratory routes. 
Ras Al-Hadd Reserve, Oman, hosts one of the largest nesting population in the world for the green turtles. Thousands of turtles migrate to the region to nest year round (Alkindi et $a l .$, 2003). Thus, choosing this species is particularly helpful in monitoring environmental marine pollution in the northern sector of the Indian Ocean. Accordingly, the present investigation will be of value to trace the sources of polluted effluents which are impacting habitats specifically along the migratory routes of marine turtles.

International cooperation is urgently needed for the implementation of the conservation programs for the preservation of this endangered species.

\section{References}

Al-Bahry, S.N., Mahmoud. I.Y., Elshafie, A.E., Al-Harthy, A., Al-Ghafri, S., Al-Amri, I., and Alkindi, A.Y., 2009a. Bacterial flora and antibiotic resistance from eggs of green turtles Chelonia mydas: an indication of polluted effluents. Marine Pollution Bulletin 41, 214-221.

Al-Bahry, S.N., Mahmoud, I.Y., Al-Belushi, K.I., Elshafie, A. E. and Al-Harthy, A., Bakheit, CK., 2009b. Coastal sewage discharge and its impact on fish with reference to antibiotic resistant enteric bacteria and enteric pathogens as bioindicators of pollution. Chemosphere 77, 1534-1539.

Al-Bahry, S.N., Mahmoud, I.Y., Al-Khaifi, A., Elshafie, A.E., and Al-Harthy, A., 2009c. Viability of multiple antibiotic resistant bacteria in distribution lines of treated sewage effluent used for irrigation. Water Science and Technology 60, 2939-2948.

Alkindi, A.Y.A., Mahmoud, I.Y., Al-Gheilani, H. M., Bakheit, C.S., Al-Habsi, A., A., and Al-Kiyumi, A., 2003. Comparative study of the nesting behavior of green turtle, Chelonia mydas, during high and low population density periods at Ras Al-Hadd Reserve, Oman. Chelonian Conservation and Biology 4, 603-611.

Alkindi, A.Y., Mahmoud, I. Y., Woller, M.J., and Plude J.L., 2006. Oviductal morphology in relation to hormonal levels in the snapping turtle, Chelydra serpentine. Tissue and cell 38, 19-33.

Alonso, A., P. Sánchez, and Martínez, J.L., 2001. Environmental selection of antibiotic resistance genes. Environmental Microbiology 3, 1-9. 
Bauer, A., Kirby, W., Sherris, W., and Turk, M., 1966. Antibiotic susceptibility testing by standard single disk method. American Journal of Clinical Pathology 45, 493-496.

Berger-Bächi, B., 2002. Resistance mechanisms of Gram-positive bacteria. International Journal of Medical Microbiology 292, 27-35.

Berrang, M., Frank, J., Jeffrey, R., Stan. J., and Cox, N., 1999. Eggshell membrane structure and penetration by Salmonella typhimurium. Journal of Food Protection 62, 7376.

Foti, M., Bottari, T, Coci, G., Daidone, A., and Pennisi, M.G., 2008. Enterobacteriaceae isolates in cloacal swabs from live-stranded internally-hooked loggerhead sea turtles, Caretta caretta, in the Central Mediterranean Sea. Journal of Herpetological Medicine and Surgery 17, 125-128.

Foti, M., Giacopello, C., Bottari, T, Fisichella, V., Rinaldo, D., and Mamminac, C., 2009. Antibiotic resistance of Gram negatives isolates from loggerhead sea turtles (Caretta caretta) in the central Mediterranean Sea. Marine Pollution Bulletin 58, 1363-1366.

Catalano, C., and S. Knabel., 1994. Destruction of Salmonella enteritidis by high pH and rapid chilling during simulated commercial egg processing. Journal of Food Prottection 57, 592-595.

Guardabassi, L., Petersen, A., Olsen, J.E., and Dalsgaard, A., 1998. Antibiotic resistance in Acinetobacter spp. isolated from sewers receiving waste effluent from a hospital and a pharmaceutical plant. Applied \& Environmental Microbiology 64: 3499-3502.

Harms, C.A., Mihnovets, A.N., Braun-McNeill, J., Kelly, T.R., Avens, L., Goodman, M.A., Goshe, L.R., Godfrey, M.H., and Hohn, A.A., 2006. Cloacal bacterial isolates and antimicrobial resistance patterns in juvenile loggerhead turtles in North Carolina, USA. In: Proceedings of Annual Symposium on Sea Turtle Conservation and Biology, p. 58.

Hühnerfuss, H., 2003. Occurrence, distribution and fate of pharmaceuticals and further polar contamination in the marine environment. PhD Dissertation. University of Hamburg. Hamburg.

Jeljaszewicz, J., Mlynarczyk, G., and Mlynarczyk, A., 2000. Antibiotic resistance in Gram-positive cocci. International Journal of Microbial Agents 16, 473-478.

Kempski, C., Rivera, J., Mfoafo, A., and Pough, H., 2005. Antibiotic resistant bacteria from Clemmys guttata (spotted turtle), Rochester Institute of Technology, Rochester, NY 14623. USA.

Kümmerer, K., 2001. Drugs in the environment: emission of drugs, diagnostic aids and disinfectants into wastewater by hospitals in relation to other sources. Chemosphere 45, 957-969. 
Kümmerer, K., 2009a. Antibiotics in the aquatic environment - A review - Part I. Chemosphere 75, 417-434.

Kümmerer, K., 2009b. Antibiotics in the aquatic environment - A review - Part II. Chemosphere 75, 435-441.

MRMEWR. 2006. Marine Pollution and Coastal Zone Management Section: Indian Ocean South-East Asian Marine Turtle Memorandum of Understanding. Ministry of Regional Municilalities and Environment and Water Resources (MRMEWR). Sultanate of Oman. http://www.ioseaturtles.org.

Miranda, C.D, and Zemelman R., 2001. Antibiotic resistant bacteria in fish from the Concepcion Bay, Chile. Marine Pollution Bulletin 42, 1096-102.

NCCLS. 1997. Performance standards for antimicrobial disk susceptibility tests, $6^{\text {th }}$ ed. Approved standard M2-A6. National Committee for Clinical Laboratory Standards, Wayne, Pa.

Refsdal, A.O., 2000. To treat or not to treat: a proper use of hormones and antibiotics. Animal Reproduction Science 60, 109-119.

Santoro, M., Hernández, G., and Caballero, M., 2006. Aerobic bacterial flora of nesting green turtles (Chelonia mydas) from Tortuguero National Park, Costa Rica. Journal of Zoo and Wildlife Medicine 37, 549-552.

Schmidt, A., Bruun, M.S., Dalsgaard, I., Pedersen, K., and Larsen, J.L., 2000. Occurrence of antimicrobial resistance in fish pathogens and environmental bacteria associated with four danish rainbow trout farms. Applied and Environmental Microbiology 66, 49084915 .

Spratt, B.G., 2004. Antibiotic resistance: Counting the cost. Current Biology 6, 12191221.

Wang, H., and M. Slavik., 1998. Bacterial penetration into eggs washed with various chemicals and stored at different temperatures and times. Journal of food Protection 1, 276-279.

\section{Acknowledgement:}

We thank Mr Majid Al-Khanjari, for his technical assistance in preparation of the drawings. 


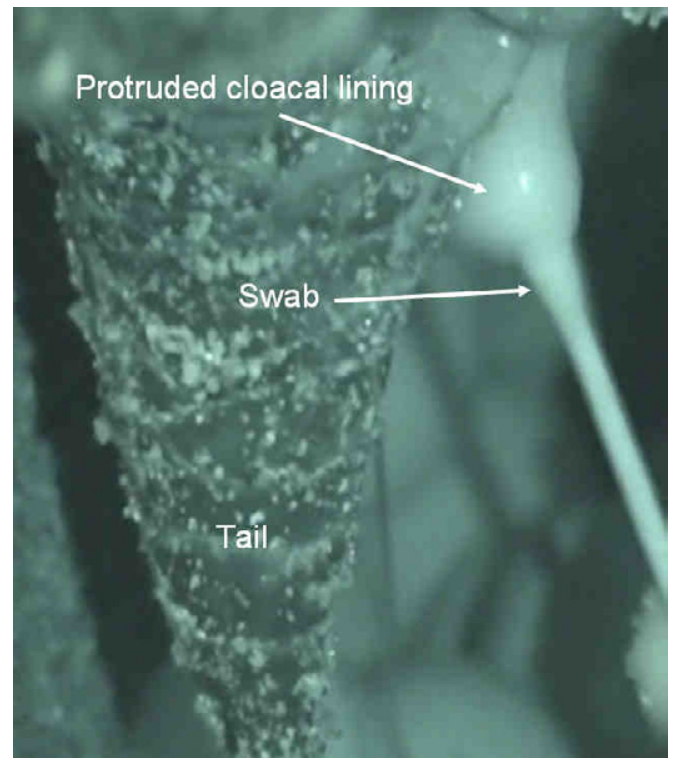

a

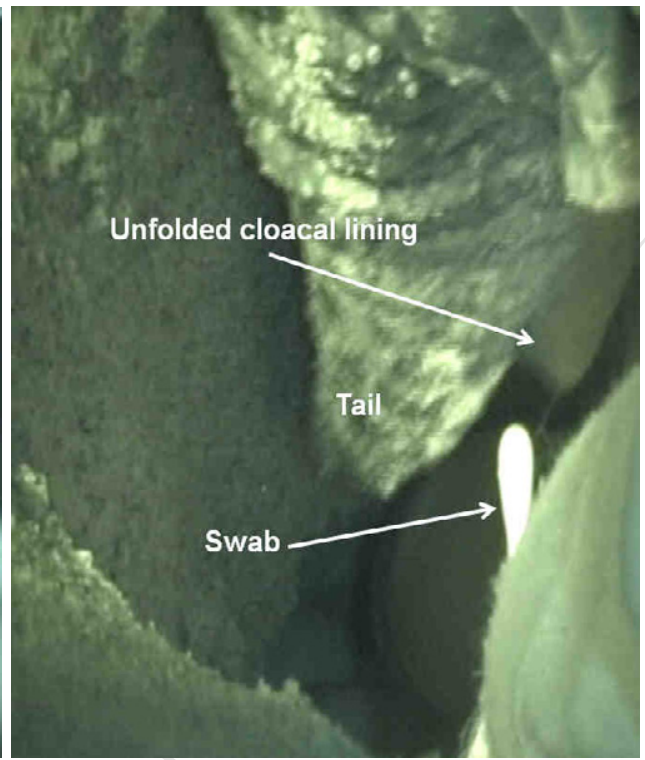

b

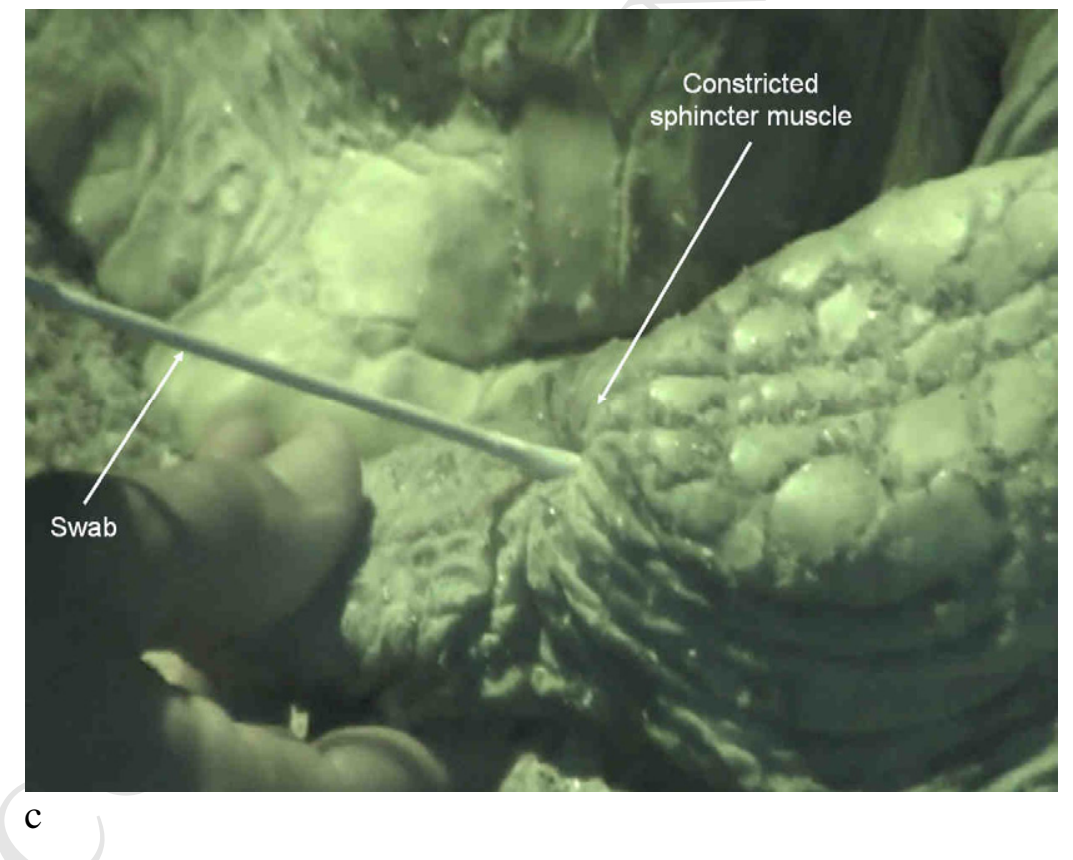

Fig. 1. Swabbing technique of oviductal fluid collection in green turtles; $a$ and $b=$ during egg-laying, note the unfolded smooth cloacal lining; $c=$ swabbing of constricted cloacal sphincter muscle showing plastron view during post egg-laying. 


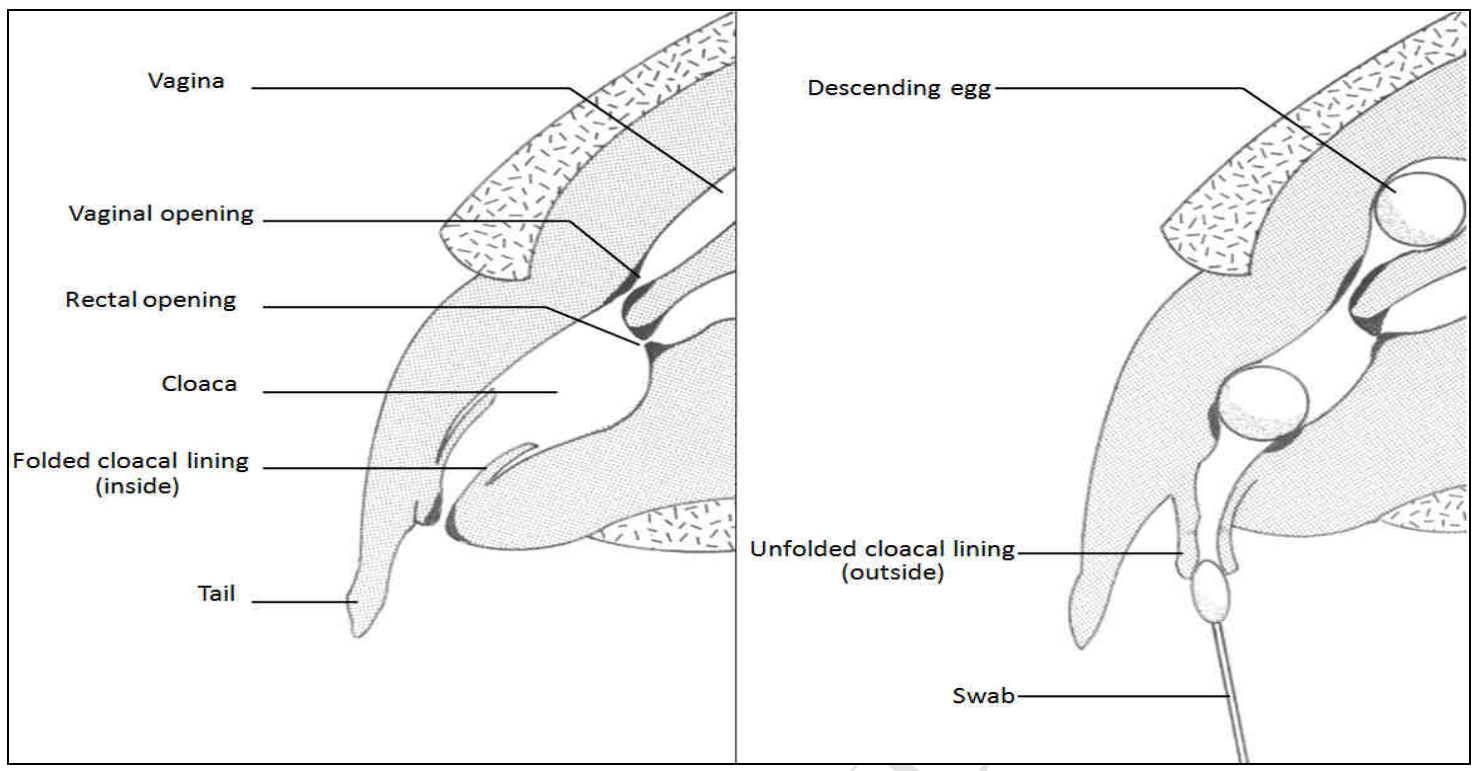

a

Fig. 2. Side view of cloaca showing the entries of vagina and gastrointestinal tract into the cloacal chamber. $\mathrm{a}=$ post egg-laying; $\mathrm{b}=$ egg lying.

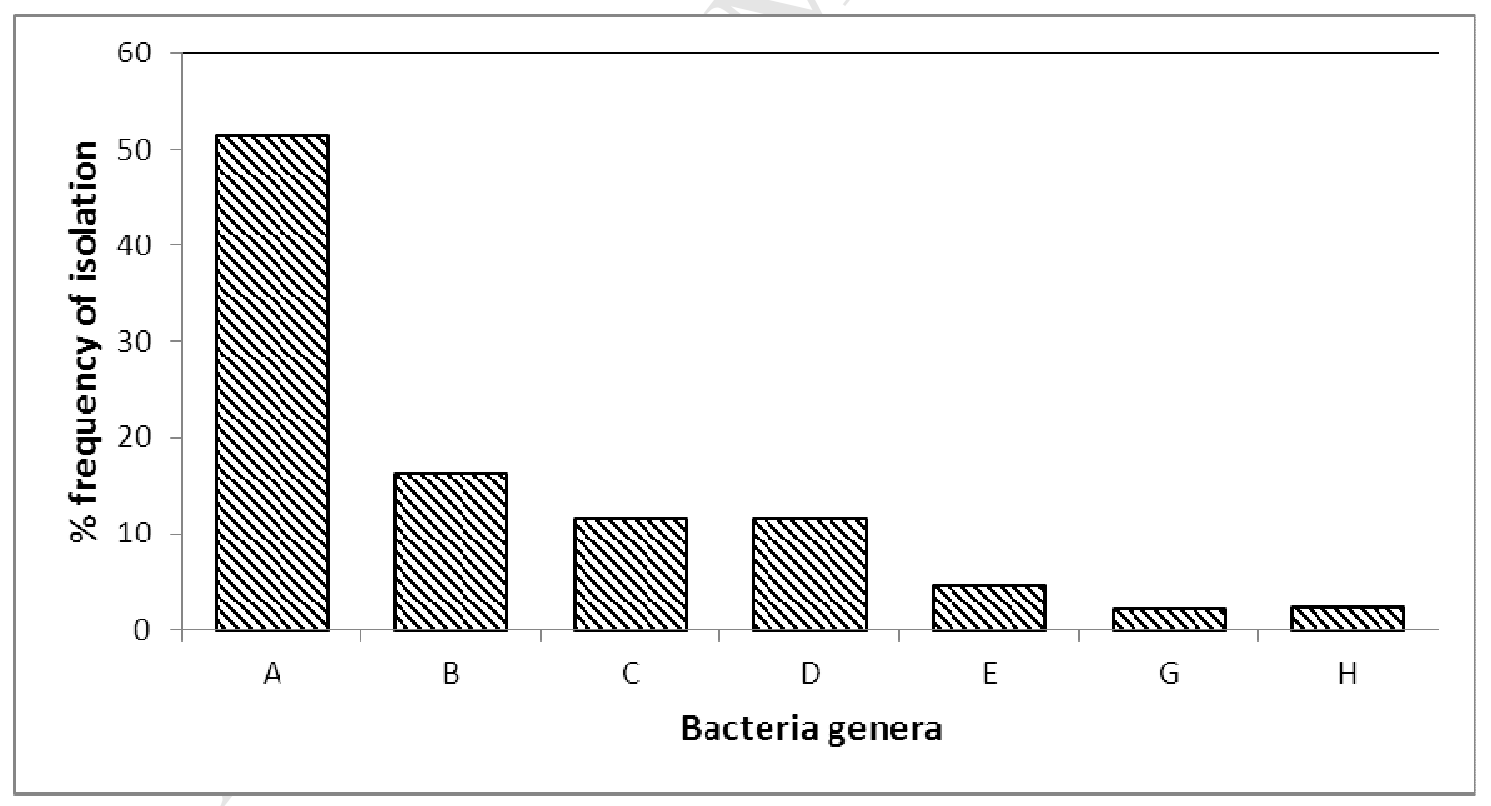

Fig. 3: Percentage frequency of bacteria isolated from the oviductal fluids.

$\mathrm{A}=$ Citrobacter $\mathrm{spp}, \mathrm{B}=$ Pasteurella $\mathrm{spp}, \mathrm{C}=$ Salmonella $\mathrm{spp}, \mathrm{D}=$ Pseudomonas $\mathrm{spp}$, $\mathrm{E}=$ Proteus spp, $\mathrm{F}=$ Aeromonas $\mathrm{spp}, \mathrm{G}=$ Shigella $\mathrm{spp}$ 


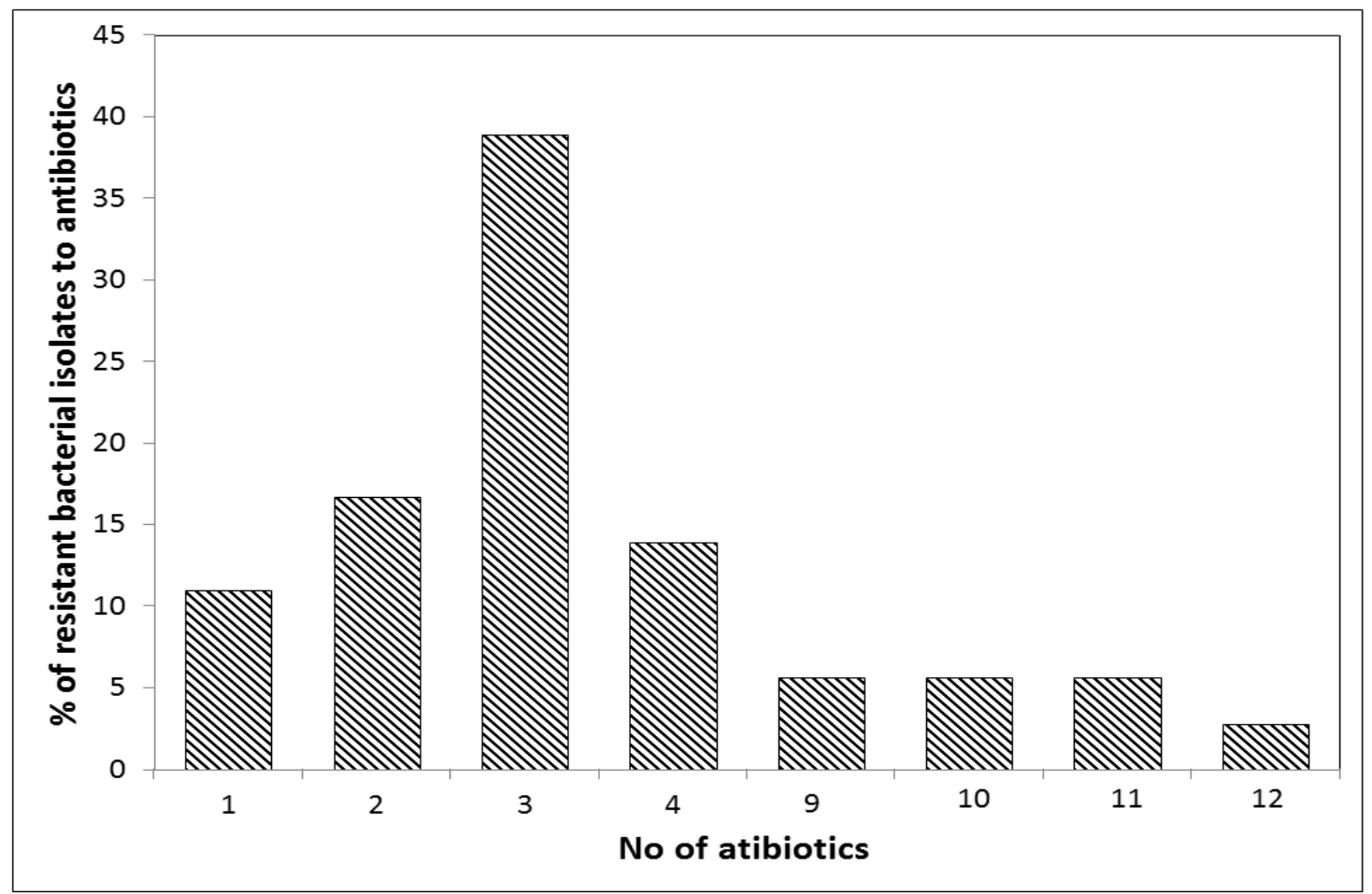

Fig. 4: Percentages of multiple resistance to antibiotics detected in bacterial isolates from oviductal fluid.

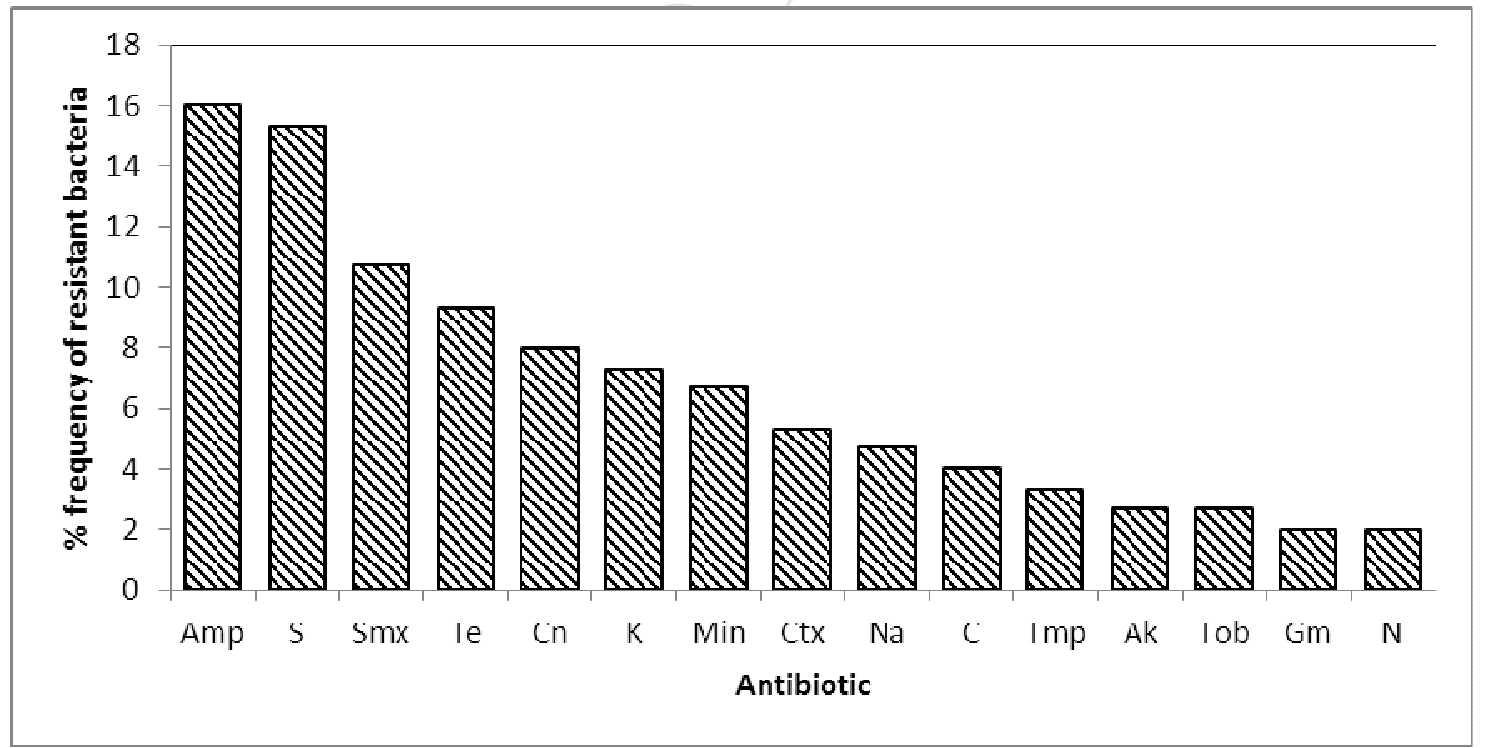

Fig. 5: Percentage frequencies of resistant bacteria to specific antibiotic. Amp = Ampicillin, $\mathrm{S}=$ Streptomycin, $\mathrm{Smx}=$ Sulphamethoxazole, $\mathrm{Te}=$ Tetracycline, $\mathrm{Cn}=$ Carbenicillin, $\mathrm{K}=$ Kanamycin, $\mathrm{Min}=$ Minocyline, $\mathrm{Ctx}=$ Cephotaxime, $\mathrm{Na}=$ Nalidixic acid, $\mathrm{C}=$ Chloramphenicol, $\mathrm{Tmp}=$ Trimethoprim, $\mathrm{Ak}=$ Amikacin, $\mathrm{Tob}=$ Tobramycin, $\mathrm{Gm}=$ Gentamicin, N=Neomycin . 